\title{
Research on Factors Affecting Capital Structure of Listed Companies Without Actual Controllers
}

\author{
Shujun Wang ${ }^{1, a,{ }^{*}}$ \\ ${ }^{1}$ Chengdu College of University of Electronic Science and Technology of China \\ afishwaterjane@126.com \\ ${ }^{*}$ Corresponding author
}

Keywords: Without actual controllers; Capital structure; Influence factor.

\begin{abstract}
Taking the listed companies without actual controllers of A-shares in China from 2009 to 2017, this paper studies the influence factors of listed companies without actual controllers through hypothesis test and model construction. This paper finds that company size, mortgage asset value, profitability has significant positive impacts on the debt level of listed companies without actual controllers. Internal accumulation level and risk control ability has significant negative effects, while the influence of company growth, bank-enterprise relationship and turnover ability is not significant.
\end{abstract}

\section{Introduction}

In recent years, many events have aroused widespread concern in the society for listed companies without actual controllers, such as the battle between Vanke A (000002) and Baoneng's stock rights and the Sunshine Insurance's purchase of equity for domestic dairy giant Yili (600887). Without actual controllers, the ownership and control rights are more dispersed, while the power checks and balances and interests encroachment are more sophisticated, which may influence the development of enterprises and play a negative role in the interests of small and medium shareholders and the sound development of the market. Therefore, it is very essential to study the financial behavior and market performance of listed companies without actual controllers. However, as the key content of financial theory, capital structure is the most important issue of studying the financial behavior of listed companies without actual controllers. The so-called capital structure generally refers to the composition of an enterprise's total capital, that is, the proportional relationship between liabilities and its own capital. Capital structure has profound internal influence on corporate governance, strategic choice and value growth. Therefore, it is extremely vital for analyzing the influence factors of the capital structure of listed companies without actual controllers.

\section{Literature review and research assumptions}

\subsection{Literature review}

Since Modigliani and Miller (1958) published the classic paper "Capital Cost, Corporate Finance and Investment Theory", the issue of capital structure has attracted extensive attention in academia. As MM theory pointed, the enterprise value has nothing to do with the capital structure under the assumption that there is no bankruptcy or tax, capital can flow freely and the financial market is effective. However, these assumptions are not established in reality. In fact, enterprises actually cost a lot of resources to define the capital structure. Subsequently, scholars relaxed these assumptions and carried out broad research about the role of the taxation, bankruptcy costs, information asymmetry as well as the corporate governance structure in the choice of corporate capital structure and financing behavior.

Regarding the internal factors that affect the capital structure of an enterprise, Matos (2001) studies the relationship between dividend distribution and financing who believes that the two have influence on each other. Fama, French (1997) and Marsh (1982) believe that taxes, bankruptcy costs and enterprise growth will affect the capital structure of enterprises. Rajan and Zingales (1995) and Booth (2000) respectively studies the influencing factors of corporate capital structure with mature 
markets and emerging markets as samples, which found that the factors of influence varied from country to country. Through a questionnaire survey, Graham (2001) finds that future operating results, taxes, financing costs and even the education background of the finance director will affect corporate financing and capital structure.

Except for studying the internal motivation, relevant personnel also study the influence of external environment on the capital structure of enterprises. Research by Schwartz and Aronson (1967), Scott (1972), Scott and Martin (1975) and Errunza (1979) and others all show that industry has the marked impact on the corporate finance. Shleifer (1997) believes that if the interests of investors cannot be effectively protected, it will enhance the financing cost, while the external environment allows corporate financing and capital structure to deviate from the goal of maximizing shareholder value. Bradley (1984), Long (1978) and others studied the relationship between industrial characteristics and capital structure. It is found that the average debt ratio of enterprises in regulated industries is generally higher than that of enterprises in non-regulated industries, while the average debt ratio of enterprises with higher growth is higher than that of enterprises in mature industries.

\subsection{Research assumptions}

As many documents indicate, the scale of an enterprise has a direct influence on its capital structure. The larger the size of the enterprise is, the greater the risk tolerance will be, which will be more dominant in applying for loans. Therefore, hypothesis 1 is put forward: The size of the company is positively related to the level of debt, that is, if the company is large, it is easier to obtain debt financing.

Growth is an important index to measure the sustainable development of enterprises. Enterprises with strong growth have better prospects for development as well as more investment projects, which are conducive to obtaining financing from banks. Therefore, hypothesis 2 is put forward: The growth of the company is positively related to the debt level, that is, the stronger the growth, the more favorable it is for the enterprise to obtain debt financing.

Asymmetric information will have the influence on the bank's objective evaluation of corporate credit. For the sake of preventing from risks, banks will cut down the amount of corporate loans or enhance the requirements of collateral for loans. If enterprises and banks keep a good cooperative relationship with each other and reduce the information asymmetry, it will be beneficial for enterprises to acquire more debt financing. Therefore, hypothesis 3 is put forward: The relationship between banks and enterprises is positively related to the level of debt, that is, enterprises have a sound relationship with banks, which is more beneficial to enterprises to acquire the debt financing.

Turnover capability is a significant indicator to measure the operating capability of an enterprise. The stronger the operating ability of the enterprise, the smaller the operating risk, the greater the financial risk it can bear and the greater the acceptable debt pressure. Therefore, hypothesis 4 is put forward: Turnover capacity is positively related to the level of debt, that is, the stronger the turnover capacity, the more conducive to enterprises to obtain debt financing.

Enterprises have high-value mortgaged goods, while the greater the value of asset guarantee, the stronger the guarantee of debt repayment. Therefore, the level of enterprise's asset mortgage ability has direct influence on the financing capacity. Therefore, assumption 5 is put forward: Asset mortgage ability is positively related to the level of corporate debt, that is, the stronger the asset mortgage ability, the enterprise will be easier to require the debt financing.

Profitability refers to an enterprise's ability to make a profit through production and operation. When enterprises are in Financing, they will prefer to choose the internal financing. Then debt financing and equity financing based on the pecking order theory. The stronger the profitability, the enterprise will have more retained earnings, while it will have the weaker dependence on external financing so that it will have lower level of responsibility. Therefore, hypothesis 6 is put forward: Profitability is negatively related to debt level, that is, the stronger the profitability, the enterprise will be less reliance on debt financing.

Internal accumulation mainly comes from surplus reserves and undistributed profits. When internal accumulation reaches a higher level, enterprises can have more funds at their disposal, which 
are more likely to give priority to internal financing. Therefore, hypothesis 7 is put forward: Internal accumulation level is negatively related to debt level, that is, the better the internal accumulation level, the lower the dependence on debt financing.

In general, operational risks are positively related to financing risks. As a result, financial institutions prefer to choose the enterprises which have strong risk control and low operational risk to grant a loan. However, on the other hand, the enterprises with strong risk control ability have more sufficient fluid capital, which will have less dependence on debt financing. Therefore, hypothesis 8 is put forward: Risk control ability is negatively related to debt level, that is, the stronger the risk control ability, the enterprises will reduce the external financing.

\section{Design of research}

\subsection{Sample selection and data source}

The data of this paper comes from CSMAR database, which adopts the financial data of China's A-share listed companies from 2009 to 2017 without actual controllers as initial samples. In the process of selecting samples, it removes ST or *ST companies, data missing and data with obvious abnormalities as well as the financial industry companies. After screening and sorting out the data, it obtains 709 samples without actual controllers. This paper uses SPSS22 for data analysis.

\subsection{Variable design}

\subsubsection{Explained variable}

Asset-liability ratio is the proxy variable that most scholars study and analyze the capital structure of enterprises. Therefore, this paper takes advantage of asset-liability ratio to measure the capital structure of an enterprise as an explanatory variable in the empirical model, which is expressed by Finance in the model.

\subsubsection{Explanatory variable}

According to the above analysis, this paper considers the influence factors from eight aspects of company Size, company Growth, bank-enterprise Relationship, Turnover ability, asset Mortgage ability, profitability, internal Accumulation level and Risk control ability, and selects a total of eight indicators as explanatory variables, which are respectively expressed by size, growth, relation, turn over, mortgage, ROE, accumulation and risk.

\subsubsection{Control variable}

The degree of competition in the product market gives expression to the competitive power of enterprises. The paper takes the proportion of operating expenses to the main business income as the proxy scalar of the degree of competition in the product market, expressed by Competition in the model.

Corporate governance mechanism is a significant embodiment of enterprise management level and internal control capability. The paper takes the scale of independent directors as the proxy variable of corporate governance level, expressed by Govern in the model.

The explanations of various variables in this article are shown in Table 1:

Table 1 Description Table for Variable Definitions

\begin{tabular}{c|l|l|l}
\hline \multicolumn{1}{c|}{ Variable type } & \multicolumn{1}{|c|}{ Variable name } & Variable symbol & \multicolumn{1}{c}{ Variable interpretation } \\
\hline Interpreted variable & Capital structure & Finance & Debt to asset ratio \\
\hline \multirow{4}{*}{$\begin{array}{l}\text { Explanatory } \\
\text { variable }\end{array}$} & Company size & Size & Logarithm of total assets \\
\cline { 2 - 4 } & Growth of the company & Growth & Revenue growth rate \\
\cline { 2 - 4 } & Bank-enterprise relationship & Relation & Years of establishment \\
\cline { 2 - 4 } & Turnover capacity & Turnover & Total asset turnover \\
\cline { 2 - 4 } & Asset mortgage capability & Mortgage & (Fixed assets+inventory)/Total assets \\
\cline { 2 - 4 } & Profitability & ROE & Return on net assets \\
\cline { 2 - 4 } & Internal accumulation level & Accumulation & Unallocated profit/total assets \\
\cline { 2 - 4 } & Risk control capability & Risk & Current ratio \\
\hline \multirow{4}{*}{ Control variable } & $\begin{array}{l}\text { Degree of competition in } \\
\text { product market }\end{array}$ & Competition & $\begin{array}{l}\text { Operating expenses/Main business } \\
\text { income }\end{array}$ \\
\cline { 2 - 4 } & Corporate governance & Govern & $\begin{array}{l}\text { Number of independent } \\
\text { directors/Total number of directors }\end{array}$ \\
\cline { 2 - 3 } & & & \\
\hline
\end{tabular}




\subsection{Model construction}

In order to examine the hypothesis proposed in this paper, it sets up the following model:

Finance $_{i, t}$

$=\beta_{0}$

$+\beta_{1}$ Size $_{\mathrm{i}, \mathrm{t}}+\beta_{2}$ Growth $_{\mathrm{i}, \mathrm{t}}+\beta_{3}$ Relation $_{\mathrm{i}, \mathrm{t}}+\beta_{4}$ Turnover $_{\mathrm{i}, \mathrm{t}}+\beta_{5}$ Mortgage $_{\mathrm{i}, \mathrm{t}}+\beta_{6}$ ROE $_{\mathrm{i}, \mathrm{t}}+\beta_{7}$ Accumulation $_{\mathrm{i}, \mathrm{t}}+\beta_{8}$ Risk $_{\mathrm{i}, \mathrm{t}}$

$+\beta_{9} \sum$ Control $+\varepsilon_{i, t}$

In this model, Finance ${ }_{i, t}$ is the variable to be explained, which represents the financing capacity of the $\mathrm{i}$ company in the $\mathrm{t}$ year. $\beta_{0}$ is the intercept. $\beta_{1}-\beta_{9}$ are regression coefficients. $\varepsilon_{i, t}$ is the random error.

\section{Empirical results and analysis}

\subsection{Descriptive statistical analysis}

Table 2 reports descriptive statistics of major variables.

Table 2 Descriptive statistics

\begin{tabular}{l|l|l|l|l|l}
\hline Variable name & Sample size & Minimum value & Maximum value & Mean value & Standard deviation \\
\hline Finance & 709 & .0639 & .7576 & .3830 & .1796 \\
\hline Size & 709 & 18.65 & 30.99 & 23.8851 & 3.075 \\
\hline Growth & 709 & -1.2651 & 12 & .35 & 1.088 \\
\hline Relation & 709 & 5 & 35 & 18.355 & 5.5632 \\
\hline Turnover & 709 & .1455 & 2.3921 & 0.6332 & 0.4001 \\
\hline Mortgage & 709 & .0132 & .6710 & .3456 & .1654 \\
\hline ROE & 709 & -2.0517 & .2590 & .09 & .179 \\
\hline Accumulation & 709 & -0.0332 & 0.4668 & .1690 & .0895 \\
\hline Risk & 709 & .5332 & 11.0032 & 2.5634 & 1.9825 \\
\hline Competition & 709 & 1033 & .8234 & .4522 & .2532 \\
\hline Govern & 709 & 18 & .62 & .1435 & .1699 \\
\hline
\end{tabular}

\subsection{Correlation analysis}

Table 3 reports the correlation analysis results of the main variables. From the results, it can be seen that the correlation coefficient between the explanatory variables is very low, which indicates that there is no serious problem of multiple collinearity between variables. Explanatory variables that are significantly positively related to the finance capacity of the explained variables include company size and asset mortgage value, while those that are significantly negatively related are internal accumulation. Other explanatory variables also have certain correlation with the explained variables, but the significance is not high, which needs further analysis through regression.

Table 3 Pearson correlation coefficient

\begin{tabular}{|c|c|c|c|c|c|c|c|c|c|c|c|}
\hline & Finance & Size & Growth & Relation & Turnover & Mortgage & ROE & Accumulation & Risk & Competition & Govern \\
\hline Finance & 1.000 & & & & & & & & & & \\
\hline$\overline{\text { Size }}$ & $.463 * *$ & 1.000 & & & & & & & & & \\
\hline Growth & .045 & .081 & 1.000 & & & & & & & & \\
\hline Relation & .089 & .072 & -.121 & 1.000 & & & & & & & \\
\hline Turnover & $166^{*}$ & .042 & -.215 & .142 & 1.000 & & & & & & \\
\hline Mortgage & $243 * *$ & -.065 & $-159^{* *}$ & -.012 & $.139 *$ & 1.000 & & & & & \\
\hline$\overline{\mathrm{ROE}}$ & .122 & .066 & .083 & .042 & $294 * *$ & -.130 & 1.000 & & & & \\
\hline Accumulation & $-.392 * *$ & $-.421 * *$ & $-.221 * *$ & -.024 & .099 & $-.321 * *$ & $.512 * *$ & 1.000 & & & \\
\hline$\overline{\text { Risk }}$ & $-.698 * *$ & $-.345^{* *}$ & .023 & -.071 & $-.267 * *$ & $-.213 *$ & .002 & .091 & 1.000 & & \\
\hline Competition & -.065 & .053 & .019 & .033 & -.199 & .033 & .057 & -.044 & .124 & 1.000 & \\
\hline Govern & .052 & .061 & .077 & $.291 * *$ & .001 & .005 & .002 & .045 & .033 & .065 & 1.000 \\
\hline
\end{tabular}




\subsection{Multiple regression analysis}

Tables 4, 5 and 6 report the regression results of influencing factors on financing ability of listed companies without actual controllers. As it is shown in the table, the goodness of fit of the model is 0.687 , indicating that the interpretation degree of this model is $68.7 \%$. The $\mathrm{F}$ value of the model is 78.252 , and its significance level is 0.000 , which indicates that the overall significance of the model is high. As for the influencing factors of various financing capacities, the influence of company size is significantly positively correlated, which shows that larger enterprises are easier to obtain creditor's rights financing, as larger enterprises can send more positive signals. In addition, the diversified operation modes of large enterprises are more conducive to dispersing risks, which are more favored by creditors. The failure of the company growth test is not a significant factor affecting the financing ability, which may be that the growth is not directly related to the debt paying ability and the sustainable development ability, thus the improvement of the financing ability is limited. The failure of the bank-enterprise relation is not a significant factor affecting the financing capacity, which may be that it is not reasonable to use the number of years an enterprise has been established as an index to measure the bank-enterprise relation. Turnover ability has no notable influence on financing capacity, which may be due to the high degree of industry difference. The influence of the mortgage value is significantly positive, indicating that mortgage or security is one of the necessary requirements for a creditor's loan. The influence of profitability is significantly positively correlated, which indicates that enterprises with higher profitability have relatively stronger ability to repay principal and interest. In addition, it can take full advantage of financial leverage and obtain more funds through external financing. The impact of internal accumulation is significantly negatively correlated, indicating that the higher the internal accumulation level, an enterprise will have the more disposable funds and the less dependence on external financing. The influence of risk control is significantly negatively correlated, indicating that the stronger the risk control ability, the enterprise will have the stronger the debt paying ability and the more self-owned funds, thus its endogenous financing ability is stronger.

Table 4 Description of fitting of regression equation

\begin{tabular}{c|c|c|c|c}
\hline Model & $\mathrm{R}$ & R-squared & Adjusted R-squared & Error of standard estimation \\
\hline 1 & $.687 \mathrm{a}$ & .472 & .433 & .12003 \\
\hline
\end{tabular}

a. Projected value: (Constant), Size,

Growth,Relation,Turnover,Mortgage,ROE,Accumulaiton,Risk,Competition,Govern

Table 5 Significant test results of regression model

\begin{tabular}{c|c|c|c|c|c|c}
\hline \multicolumn{2}{c|}{ Model } & Sum of squares & $\mathrm{df}$ & Mean square & $\mathrm{F}$ & Sig. \\
\hline \multirow{4}{*}{1} & Regression & 6.344 & 10 & .319 & 78.252 & $.000 \mathrm{~b}$ \\
\cline { 2 - 7 } & Residual & 2.801 & 681 & .042 & & \\
\cline { 2 - 7 } & Total & 9.145 & 691 & & & \\
\hline
\end{tabular}

a. dependent variable: Finance

b. Projected value: (Constant), Size,

Growth,Relation,Turnover,Mortgage,ROE,Accumulaiton,Risk,Competition,Govern

Table 6 Regression coefficient and its significance test results

\begin{tabular}{|c|c|c|c|c|c|c|}
\hline \multirow{2}{*}{\multicolumn{2}{|c|}{ Model a }} & \multicolumn{2}{|c|}{ Non-standardiz-ation coefficient } & \multirow{2}{*}{\begin{tabular}{|c|} 
Standard coefficient \\
Beta \\
\end{tabular}} & \multirow[b]{2}{*}{$\mathrm{T}$} & \multirow[b]{2}{*}{ Sig. } \\
\hline & & $\mathrm{B}$ & Standard error & & & \\
\hline \multirow[t]{11}{*}{1} & (Constant) & -.315 & .124 & & -4.319 & .000 \\
\hline & Size & .052 & .008 & .241 & 6.124 & .000 \\
\hline & Growth & -.011 & .009 & -.041 & -1.052 & .293 \\
\hline & Relation & .001 & .001 & .015 & .466 & .640 \\
\hline & Turnover & .018 & .022 & .026 & .726 & .468 \\
\hline & Mortgage & .015 & .055 & .012 & 5.277 & .000 \\
\hline & ROE & .737 & .115 & .268 & 6.178 & .000 \\
\hline & Accumulation & -.705 & 0.101 & -.345 & -7.111 & .000 \\
\hline & Risk & -0.044 & .005 & -.409 & -10.391 & .000 \\
\hline & Competition & -.002 & .014 & -0.007 & .109 & .910 \\
\hline & Govern & 0.063 & 0.121 & 0.041 & .609 & .598 \\
\hline
\end{tabular}

a. dependent variable: Finance 


\section{Summary}

This paper found that company size, asset mortgage value and profitability have significant positive influences on the financing ability of listed companies. Internal accumulation level and risk control ability have significant negative effects on the capital structure level of listed companies without actual controllers. The influence of company growth, bank-enterprise relationship and turnover ability is not significant. According to the conclusions of this paper, the following recommendations are propsed.

Firstly, it should enhance the development capacity of enterprises. The size of the company can improve the financing ability of the enterprise significantly, while the expansion of the company's size depends on the overall development. Therefore, enhancing the development ability of enterprises and forging the core competitiveness can remain invincible in the volatile market competition. Second, it should enhance the enterprise's endogenous financing capacity. A company that relies solely on foreign financing is difficult to sustain healthily. Effective profitability and internal incentive level can enhance the endogenous financing ability of enterprises, cut down the financial risks of enterprises, which will promote the improvement of enterprise financing capacity in the end. Finally, it should strengthen the financial management construction of enterprises. Reinforcing the construction of enterprise's financial system and perfecting the financial management system contribute to improving the information asymmetry in the enterprise's financing process, which will enhance the enterprise's financing ability.

\section{Reference}

[1] Modigliani, Franco and Merton H. Miller, The Cost of Capital, Corporation Finance and the Theory of Investment, American Economic Review, 1958,48(3):261-297.

[2] Modigliani, Franco and Merton H. Miller, Corporatic Incomes Taxes and The Cost of Capital: A correction, American Economic Review,1963,53(3):433-443.

[3] Jiang Fuxiu, Liu Zhibiao, etc. Research on Structural Differences between Companies in Different Industries J. Journal of Financial Research, 2008, (5):172-185.

[4] Lu Zhengfei, Xin Yu. An Empirical Study on Main Influencing Factors of Capital Structure of Listed Companies J. Economic Research Journal, 1999,39-47.

[5] Su Kun, Zhang Junrui. Ultimate Control Right and Capital Structure Decision J. Chinese Journal of Management, 2012,03:466-472.

[6] Zhu Wuxiang, Wei Wei, Wang Zhengwei. Return to Classics: Reflections on the Study of Capital Structure for 60 Years J. Journal of Financial Research, 2014,12:194-206. 